\title{
TAILORING THE INTERGRANULAR PHASES IN SILICON NITRIDE FOR IMPROVED TOUGHNESS
}

E. Y. Sun, P. F. Becher, K. P. Plucknett and S. B. Waters

$$
\text { CONF- } 96 / 202 \cdot-17
$$

Metals and Ceramics Division, Oak Ridge National Laboratory, Oak Ridge, TN 37831-6068

K. Hirao and M. E. Brito

National Industrial Research Institute of Nagoya, Nagoya, Japan

fis.

DEC I 91860

ABSTRACT

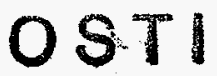

Intergranular glass phases can have a significant influence on the fracture resistance $(R$ curve behavior) of silicon nitride ceramics and appears to be related to the debonding of the $\beta$ $\mathrm{Si}_{3} \mathrm{~N}_{4}$ /oxynitride-glass interfaces. Applying the results from $\beta$ - $\mathrm{Si}_{3} \mathrm{~N}_{4}$-whisker/oxynitride-glass model systems, self-reinforced silicon nitrides with different sintering additive ratios were investigated. Silicon nitrides sintered with a lower $\mathrm{Al}_{2} \mathrm{O}_{3}: \mathrm{Y}_{2} \mathrm{O}_{3}$ additive ratio exhibited higher steady-state fracture toughness together with a steeply-rising $R$-curve. Analytical electron microscopy studies suggested that the different fracture behavior is related to the Al content in the SiAlON growth band on the elongated grains, which could result in differences in interfacial bonding structures between the grains and the intergranular glass.

\section{INTRODUCTION}

The fracture resistance of self-reinforced silicon nitride ceramics is strongly influenced by the interfacial fracture behavior between the large elongated $\beta-\mathrm{Si}_{3} \mathrm{~N}_{4}$ grains and the intergranular amorphous phase. Toughening mechanisms such as crack-deflection and crackbridging are activated via the interfacial debonding process. It has been observed that silicon nitrides processed with different densification additives can exhibit similar microstructures but very different fracture behaviors $[1,2]$. In the present study, the effect of sintering additives on the interfacial debonding behavior was first approached by using model systems with $\beta-\mathrm{Si}_{3} \mathrm{~N}_{4}$ whiskers dispersed in oxynitride glasses and systematically varying the glass composition. The results were then applied to the silicon nitride ceramics by controlling the $\mathrm{Y}: \mathrm{Al}$ ratio in the sintering additives. The microstructure of the silicon nitrides was regulated by incorporating rod-like $\beta-\mathrm{Si}_{3} \mathrm{~N}_{4}$ single crystal seeds into the ceramics. The steady-state toughness values of the seeded silicon nitrides were compared and related to structural/chemistry characterizations to address the microstructural origin of the different fracture behaviors.

\section{EXPERIMENT}

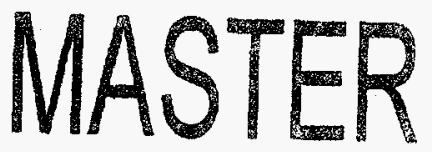

The processing parameters and the compositions of the glasses in the $\beta-\mathrm{Si}_{3} \mathrm{~N}_{4-}$ whisker/oxynitride-glass model systems are listed in Table 1 . The processing procedures of the whisker/glass systems and the measurements of the linear thermal expansion coefficients $(\alpha)$ and the glass transition temperatures $\left(T_{\mathrm{g}}\right)$ were described in detail in Refs. 3 and 4 . The interfacial debonding behavior was evaluated by an indentation-induced crack-deflection method, as illustrated by the schematic diagram in Figure 1(a). The results are plotted with the interfacial debonding length $\left(l_{\mathrm{db}}\right)$ versus the angle of incidence $(\theta)$. The interfacial debonding energy in different systems can be assessed by comparing the maximum angle of incidence for the onset of interfacial debonding $\left(\theta_{\text {crit }}\right)$ and $l_{\mathrm{db}}$ (Figure 1(b)). 


\section{DISCLAIMER}

This report was prepared as an account of work sponsored by an agency of the United States Government. Neither the United States Government nor any agency thereof, nor any of their employees, makes any warranty, express or implied, or assumes any legal liability or responsibility for the accuracy, completeness, or usefulness of any information, apparatus, product, or process disclosed, or represents that its use would not infringe privately owned rights. Reference herein to any specific commercial product, process, or service by trade name, trademark, manufacturer, or otherwise does not necessarily constitute or imply its endorsement, recommendation, or favoring by the United States Government or any agency thereof. The views and opinions of authors expressed herein do not necessarily state or reflect those of the United States Government or any agency thereof. 


\section{DISCLATMER}

Portions of this document may be illegible in electronic image products. Images are produced from the best available original document. 
Table 1. Compositions and processing conditions of the $\beta-\mathrm{Si}_{3} \mathrm{~N}_{4}$-whisker/oxynitride-glass model systems.

\begin{tabular}{|c|c|c|c|c|c|c|c|}
\hline \multirow[t]{2}{*}{ System } & \multicolumn{5}{|c|}{ Composition (eq.\%) } & \multirow{2}{*}{$\begin{array}{r}\text { Temp. } \\
\left({ }^{\circ} \mathrm{C}\right)\end{array}$} & \multirow{2}{*}{$\begin{array}{c}\text { Time at Temp. } \\
\text { (min.) }\end{array}$} \\
\hline & $\mathrm{Si}$ & $\mathrm{Al}$ & $\mathrm{Y}$ or $\mathrm{RE}$ & $\mathrm{O}$ & $\mathrm{N}$ & & \\
\hline AlY20-I & 55 & 25 & 20 & 80 & 20 & 1700 & 6 \\
\hline YAl20-I & 55 & 10 & 35 & 80 & 20 & 1700 & 8 \\
\hline AlY20-II & 55 & 25 & 20 & 80 & 20 & $1600^{*}$ & $60^{*}$ \\
\hline YAl20-II & 55 & 10 & 35 & 80 & 20 & $1600^{*}$ & $60^{*}$ \\
\hline LaAl & 50 & 25 & 25 & 67 & 33 & 1680 & 30 \\
\hline $\mathrm{La}$ & 57 & 0 & 43 & 79 & 21 & 1700 & 4 \\
\hline
\end{tabular}

*AIY20-II and YAl20-II were obtained by annealing AlY20-I and YAl20-I under these conditions.

(a)

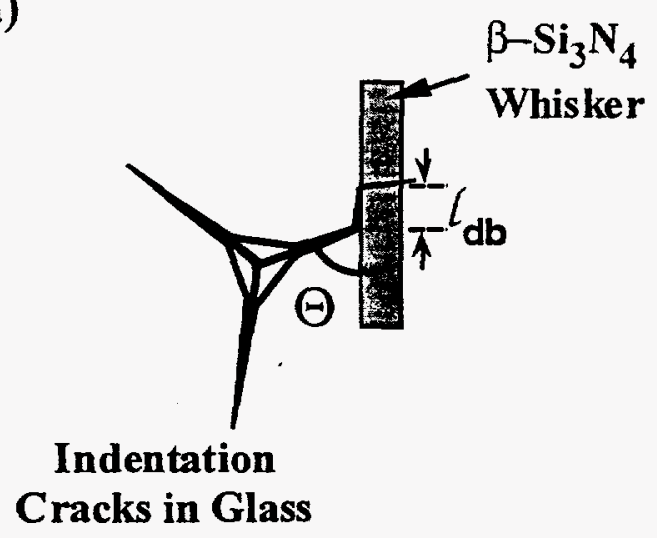

(b)

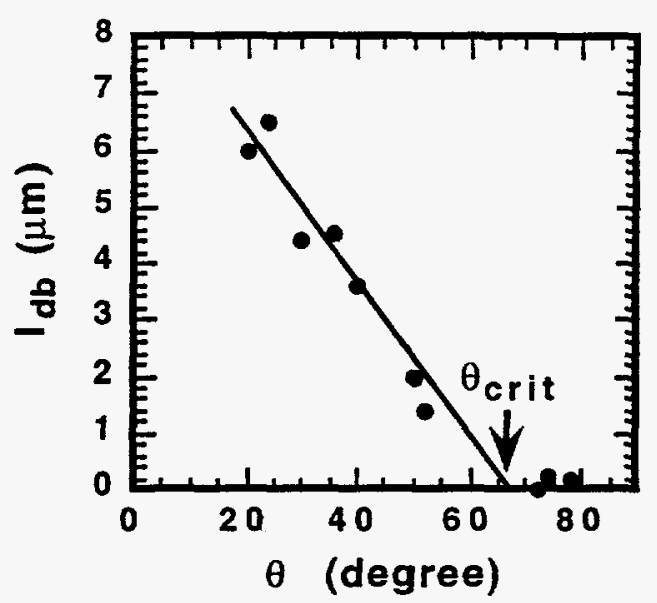

Figure 1. (a) Schematic diagram of the debonding experiment; and (b) data analyses of the debonding experiment. $\theta_{\text {crit }}$ can be determined by plotting $l_{\mathrm{db}}$ versus $\theta$.

Seeded silicon nitrides with $2 \mathrm{wt} . \% \beta-\mathrm{Si}_{3} \mathrm{~N}_{4}$ single crystal seeds were processed using tapecasting and gas pressure sintering, following the procedures in Refs. 5-6. Three different Al:Y ratios were studied: $3: 2,1: 1$ and $1: 3$ in eq.\% (i.e. $\mathrm{Al}_{2} \mathrm{O}_{3}: \mathrm{Y}_{2} \mathrm{O}_{3}$ ratios: 2.8:4, 2:5 and 1:6.25 in wt.\%). A fine-grain silicon nitride without seeds was also prepared as a reference. The microstructure of the materials was characterized using scanning electron microscopy (SEM) and transmission electron microscopy (TEM). Composition analyses of the microstructures were conducted using energy dispersive $x$-ray spectrometry (EDS) in the SEM and TEM. The $R$-curve response of the seeded/un-seeded silicon nitrides was investigated using an applied moment double cantilever beam (DCB) geometry with the crack plane oriented both perpendicular and parallel to the tape-casting direction. The DCB sample was precracked with an initial crack length between 50-200 $\mu \mathrm{m}$. Details on the testing module and sample preparation can be found in Ref. 7. During the experiments, the testing stage was placed either in the chamber of an SEM or on the stage of an optical microscope for direct observation of crack interacting with microstructures. 
Interfacial Fractural Behavior in the $\beta-\mathrm{Si}_{2} \mathrm{~N}_{1}-$ Whisker/Oxvnitride-Glass Model Systems

The interfacial debonding behavior in the $\beta-\mathrm{Si}_{3} \mathrm{~N}_{4}$-whisker/oxynitride-glass model systems was strongly influenced by the interfacial microstructure and chemistry. In oxynitride glasses containing $\mathrm{Al}$ and with high nitrogen concentrations, growth of $\beta^{\prime}-\mathrm{SiAlON}$ on the $\beta-\mathrm{Si}_{3} \mathrm{~N}_{4}$ whiskers is thermodynamically favorable. Results of the debonding experiments and microstructural characterizations revealed that $\mathrm{SiAlON}$-formation at the $\beta-\mathrm{Si}_{3} \mathrm{~N}_{4}$-whisker/glass interface was associated with decreases in $\theta_{\text {crit }}$ and $l_{\mathrm{db}}$. Figure 2(a) shows an example how the debonding behaviors is influenced by the interfacial microstructure. In system AlY20-I, a 150$250 \mathrm{~nm}$ thick SiAlON layer formed during processing at high temperatures. A subsequent heattreatment slightly increased the thickness of the SiAlON layer. Thus system AlY20-II exhibited similar debonding behavior as system AlY20-I. On the other hand, a similar heat-treatment altered the debonding behavior dramatically in system YAl20. With this particular glass composition, SiAlON growth occurred after a prolonged period at high temperatures. No SiAlON formation occurred in system YAl20-I and it exhibited higher $\theta_{\text {crit }}$ and $l_{\mathrm{db}}$ values than the other three systems. To inhibit SiAlON growth and study the interfacial debonding behavior in Alfree systems, a comparison was made between the $\mathrm{LaAl}$ and $\mathrm{La}$ systems. As shown in Figure 2(b), the Al-free system exhibited higher $\theta_{\text {crit }}$ and $l_{\mathrm{db}}$ values compared to the Al-based system where SiAlON formed at the interface. Therefore, SiAlON formation at the the whisker/glass interface resulted in an increase in the interfacial debonding energy.

Interfacial Fractural Behavior in the Seeded Silicon Nitrides Densified with Different Additives

The interfacial fracture behavior in seeded silicon nitrides varied as a function of the $\mathrm{Al}$ concentration at the grain boundary interface. Because the ceramics were sintered at high temperatures for a long period of time (usually several hours), SiAlON growth on the
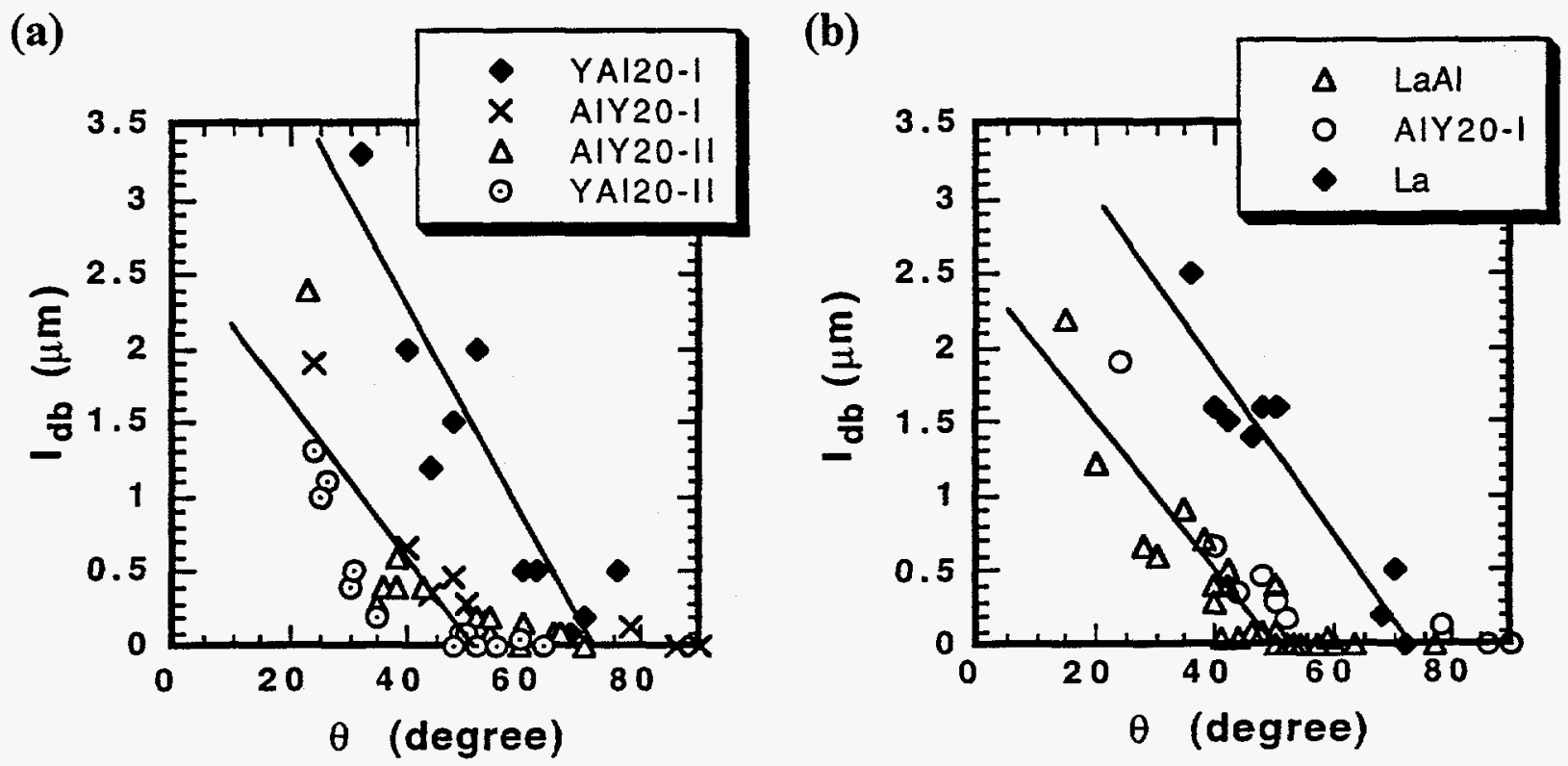

Figure 2. Interfacial debonding behavior: (a) in systems AlY20 and YAl20 before and after annealing treatments; and (b) in the $\mathrm{LaAl}$ and $\mathrm{La}$ based systems. 


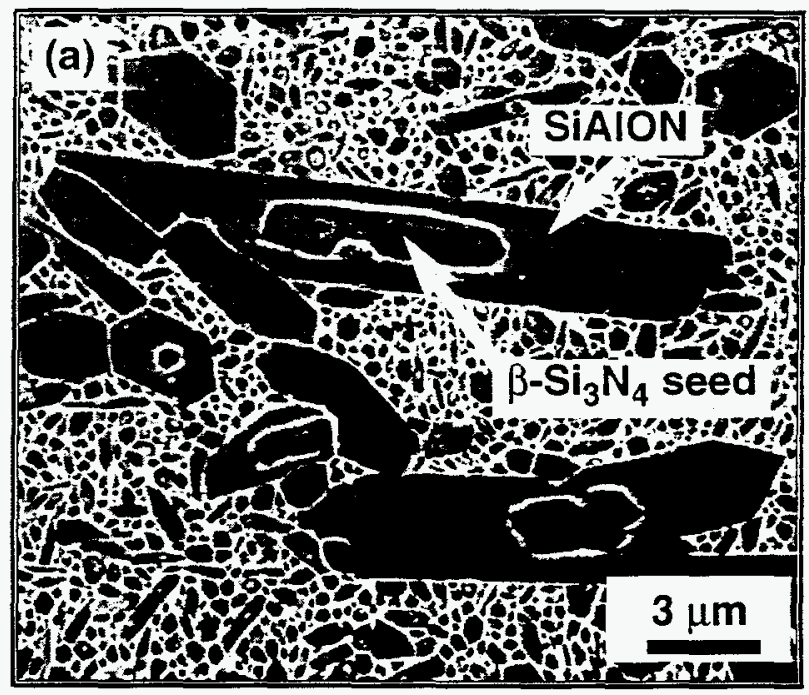

(b)

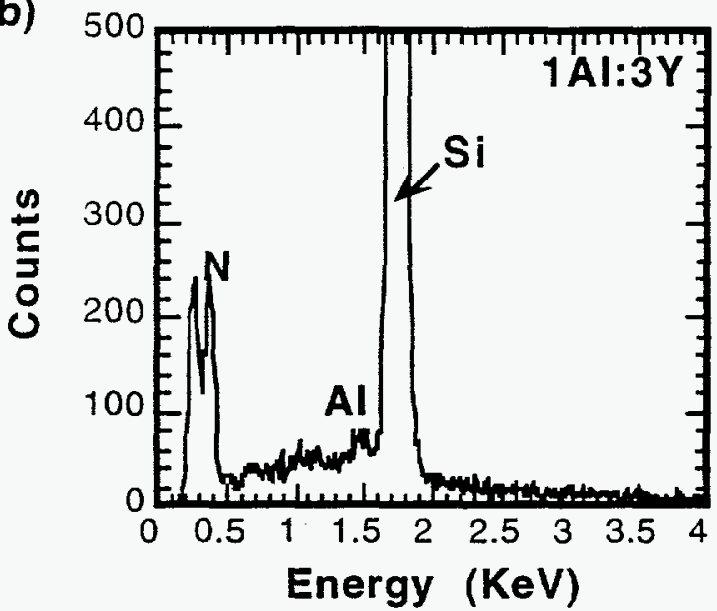

(c)

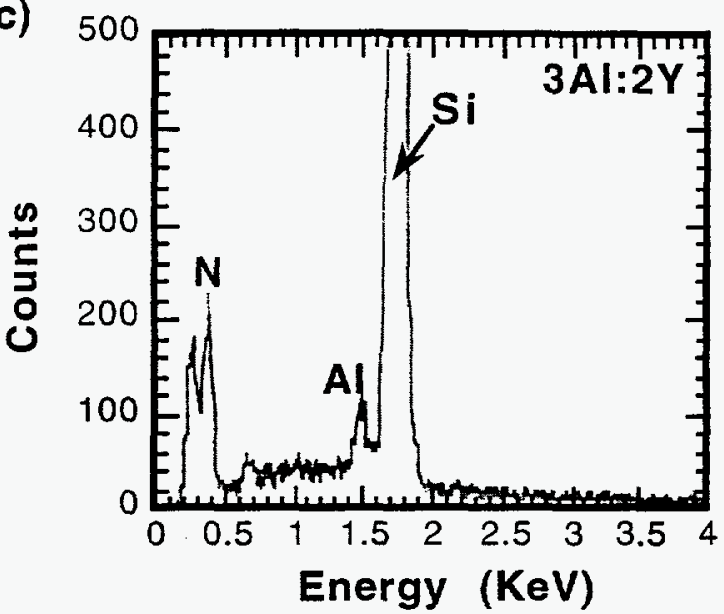

Figure 3. (a) Typical SiAlON-growth structure in the seeded silicon nitride ceramics. EDS spectra of the $\mathrm{SiAlON}$ layer on the large elongated $\beta-\mathrm{Si}_{3} \mathrm{~N}_{4}$ grains were collected in samples with the lowest (b) and highest $\mathrm{Al}$ : $\mathrm{Y}$ ratios (c).

$\beta-\mathrm{Si}_{3} \mathrm{~N}_{4}$ seeds occurred in all the three compositions (Figure 3(a)). However, the Al content in the SiAlON growth layer and the intergranular glassy phase varied accordingly to the Al:Y ratio in the sintering additives. Figures 3(b) and 3(c) are EDS spectra from the SiAION layers in samples processed with the lowest and highest Al:Y ratios. The Al peak was barely detectable in the samples with the lowest $\mathrm{Al}: \mathrm{Y}$ ratio. In-situ observations of crack interactions with microstructures revealed extensive interfacial debonding and intergranular failure associated with the large elongated $\beta-\mathrm{Si}_{3} \mathrm{~N}_{4}$ grains in this composition. On the other hand, the interfacial bonding between the large elongated $\beta-\mathrm{Si}_{3} \mathrm{~N}_{4}$ grains and the surrounding matrix was strong in the sample with the highest $\mathrm{Al}: \mathrm{Y}$ ratio. Most of the elongated grains failed transgranularly. Table 2 lists the steady-state toughness values measured during $R$-curve observations. The material with the lowest $\mathrm{Al}: \mathrm{Y}$ ratio exhibited high steady-state toughness values and steeplyrising $R$-curres; while the material with the highest $\mathrm{Al}: \mathrm{Y}$ ratio exhibited only a minor improvement in the fracture resistance compared to the fine-grain ceramic, indicating limited contribution from the large elongated grains. 
Table 2. Steady-state toughness values of the seeded silicon nitride ceramics with different sintering additives. The steady-state toughness value of a fine-grain silicon nitride without seeds is also listed as a reference.

\begin{tabular}{ccc}
\hline $\begin{array}{c}\text { Sintering Additives } \\
\text { (eq.\%) }\end{array}$ & Seeded & $\begin{array}{c}\text { Steady-State Toughness* } \\
\text { (MPa } \sqrt{\mathrm{m}})\end{array}$ \\
\hline 1Al:1Y & no & 7.0 \\
$3 \mathrm{Al}: 2 \mathrm{Y}$ & yes & 7.7 \\
1Al:1Y & yes & 8.6 \\
1Al:3Y & yes & 10.6 \\
\hline
\end{tabular}

*The crack planes were perpendicular to the tape-casting direction.

\section{DISCUSSION}

The interfacial fracture behavior in both the $\beta-\mathrm{Si}_{3} \mathrm{~N}_{4}$-whisker/oxynitride-glass model systems and the seeded silicon nitride ceramics is strongly influenced by the glass chemistry. In the model systems, an epitaxy $\beta^{\prime}$-SiAlON layer grew on the $\beta-S_{3} \mathrm{~N}_{4}$ grain in Al-based oxynitride glasses under certain processing conditions. Formation of $\beta^{\prime}-\mathrm{SiAlON}$ induced Al-N, $\mathrm{Al}-\mathrm{O}$ and $\mathrm{Si}-\mathrm{O}$ bonds into the surface region of the whiskers. Since the major atomic bonds in the Si-Al-Y oxynitride glasses are $\mathrm{Si}-\mathrm{O}, \mathrm{Si}-\mathrm{N}, \mathrm{Al}-\mathrm{N}$ and $\mathrm{Al}-\mathrm{O}$, the bonding structure across the $\mathrm{SiAlON/glass} \mathrm{interface} \mathrm{would} \mathrm{be} \mathrm{more} \mathrm{continuous} \mathrm{and} \mathrm{integrated} \mathrm{than} \mathrm{that} \mathrm{across} \mathrm{the}$ $\mathrm{Si}_{3} \mathrm{~N}_{4} /$ glass interface. The SiAlON/glass interface is more strongly chemically bonded than the $\mathrm{Si}_{3} \mathrm{~N}_{4}$ /glass interface and exhibits a higher interfacial debonding energy compared to the $\beta$ $\mathrm{Si}_{3} \mathrm{~N}_{4}$ /oxynitride-glass interface. With the same argument, it can be expected that the bonding strength at the $\beta^{\prime}$-SiAlON/Si-Y-Al-oxynitride-glass interface could be influenced by the $\mathrm{Al}$ concentration in the $\beta^{\prime}$-SiAlON layer. Increasing the number of Al-O, Al-N and Si-O bonds in the SiAlON layer near the interface could induce more "bonding sites" across the interface. This is especially relevant when the $\mathrm{Al}$ concentration in the SiAlON is very low such that a small change in the amount of $\mathrm{Al}$ at the interface could alter the bonding structure significantly, resulting in different interfacial debonding behaviors as demonstrated in the seeded silicon nitrides.

\section{CONCLUSIONS}

In silicon nitride based material systems, the interfacial fracture behavior is strongly influenced by the interfacial microstructure and chemistry. First, the interfacial debonding strength of a $\beta-\mathrm{Si}_{3} \mathrm{~N}_{4}$ /oxynitride-glass interface is lower than that of a $\beta^{\prime}$-SiAlON/oxynitride glass interface. Second, the interfacial debonding energy at the $\beta^{\prime}$-SiAlON/oxynitride-glass interface is sensitive to the $\mathrm{Al}$ concentration in the SiAlON layer, especially when the $\mathrm{Al}$ concentration is very low. For silicon nitrides densified using alumina and yttria, significant improvement in the $R$-curve behavior and the steady-state fracture toughness values can be obtained using a low Al:Y ratio. The improvement in the fracture resistance resulted from extensive debonding at grain boundary interfaces and thus intergranular fracture of the large elongated grains. 
The authors thank Dr. M. K. Ferber and Dr. H. T. Lin for reviewing the manuscript. Research is sponsored by the U.S. Department of Energy, Division of Materials Sciences, office of Basic Energy Sciences, under contract DE-AC05-96OR22464 with Lockheed Martin Energy Research Corp. and by appointments of EYS and KPP to the Oak Ridge National Laboratory Postdoctoral Research Associates Program, which is administered jointly by the Oak Ridge Institute for Science and Education and Oak Ridge National Laboratory.

\section{REFERENCES}

1. G. Wotting and G. Ziegler, Ceramics Int., 10, 18 (1984).

2. Y. Tajima, in Silicon Nitride Ceramics - Scientific and Technological Advances, edited by I. W. Chen, P. F. Becher, M. Mitomo, G. Petzow and T. S. Yen (MRS Proc. Vol. 287, Pittsburgh, PA, 1993) pp. 189-196.

3. P. F. Becher, E. Y. Sun, C. H. Hsueh, K. B. Alexander, S. L. Hwang, S. B. Waters and C. G. Westmoreland, Acta Mater., 44, 3881(1996).

4. E. Y. Sun, P. F. Becher, S. L. Hwang, S. B. Waters, G. M. Pharr, and T. Y. Tsui, J. Non-Cryst. Solids, in press.

5. K. Hirao, T. Hagaoka, M. E. Brito, and S. Kanzaki, J. Am. Ceram. Soc., 78, 1687 (1995).

6. K. Hirao, A. Tsuge, M. E. Brito, and S. Kanzaki, J. Am. Ceram. Soc. Jpn., 101, 1051 (1993).

7. P. F. Becher, C. H. Hsueh, K. B. Alexander, and E. Y. Sun, J. Am. Ceram. Soc., 79, 298 (1996). 